\title{
Basin clawbacks: reducing overallocation and the right to water
}

\author{
F. Rochford \\ La Trobe University, Australia
}

\begin{abstract}
Overallocation of irrigation entitlements has occurred in many developed river basins. In the Murray Darling Basin in Australia the Water Act 2007 (Cth) requires the establishment of a Basin Plan that will set the requirements for all water resource plans across the Basin. It is anticipated that it will significantly cut irrigation allocations across the Basin. This paper will consider the means by which Australian jurisdictions have reduced and will further reduce allocations, and assess whether these strategies can be translated to American jurisdictions. Emerging issues relating to Constitutional takings in the Australian jurisdiction reflect a much more fully developed jurisprudence in the United States. The strategies for allocation clawback are restricted by the requirement to provide 'just terms'. The means by which this Constitutional protection frames mechanisms for reducing overallocation are considered, and emerging conceptions of the right to water assessed.
\end{abstract}

Keywords: water, law, policy, human rights.

\section{Introduction}

Water is a perennial issue in the notoriously variable Australian climate. Echoing the Federation debates of the 1890s [1], the first decade of this millennium was marked by increasing concern about water security in the face of a decade-long drought [2]. In this context, a political consensus arose as to the need to correct the overallocation of water in the Murray Darling Basin. Supplementing a suite of Constitutional powers patched together by the Federal government, States handed over some of their Constitutional powers to the Commonwealth to effect Basin-wide reforms under the Constitutional provision s.51 (xxxvii). The Water Act 2007 (Cth) was the result. Under that Act, and 
following an extensive period of research and consultation, a Guide to a Proposed Basin Plan [3] was formulated.

The proposed Plan indicates that irrigators will be likely to have their water allocations cut by up to $45 \%$ to achieve a reduction of between 3,000 and 4,000 gigalitres to fulfil environmental obligations imposed by the Act [3].

The proposals have met with furious responses, particularly from irrigators and irrigation communities convinced that the proposed cuts would render their agricultural enterprises unviable $[4,5]$. The Federal Government faced a backlash over a perceived failure to balance environmental and social effects [6] and the head of the Murray Darling Basin Authority resigned [7]. The Federal Government, in power only on the basis of a negotiated agreement with rural independents, agreed to a federal parliamentary inquiry on the impact of water cuts on communities.

Characteristically, this drought has been broken by devastating floods $[8,9]$, and the federal leader of the opposition has re-introduced the political gamechanger - the potential for new dam-building in the Basin, introducing new water supplies, possibly mitigating flood damage, but also rewriting the consensus on river extractions [10,11]. Irrigators have called for a rethink on the need to return such volumes of water to the environment [12]. At present, however, the federal government currently remains committed to the Murray Darling Basin Plan [13].

This paper will consider the model by which cuts in water allocations are projected to occur under the proposed basin plan. It will then consider the implications of reallocation from the perspective of the inchoate right to water. It will conclude that the issue of reallocation is not as important as the issue of infrastructure - that if a right to access potable water at a reasonable cost exists in Australia then the potential to achieve it is likely to diminish, rather than improve, under the projected arrangements.

\section{The Basin Plan}

Water management and allocation in Australia is a state matter, so up until recently attempts to manage the enormous Murray Darling Basin, which traverses four states - Queensland, New South Wales, Victoria and South Australia - and one Territory - the Australian Capital Territory - were a patchwork of compromises and agreements at a political level. The debates in relation to water in the Australian Constitutional Conventions had ranged around the question of federal administration of water resources [14], but the emphatic rejection of that option was contained in s.100 of the Constitution, which contained an express reservation that 'The Commonwealth shall not, by any law or regulation of trade or commerce, abridge the right of a State or of the residents therein to the reasonable use of the waters of rivers for conservation or irrigation.' Instead, the Commonwealth, states and territories entered into interjurisdictional agreements, given effect by state and territory legislation. During the course of the twentieth century, however, the perceived need for uniformity in a range of economic areas, such as competition policy and corporations law, 
started to affect an increasing number of areas. The Council of Australian Governments (CoAG) Intergovernmental Agreement on a National Water Initiative [15] had as its central premise the creation of a national market for water, necessitating uniformity in water governance mechanisms across states. State governments' compliance with these measures was prompted by tranche payments from the federal government.

A decade-long drought at the close of the twentieth century, in the context of a growing population and growing awareness of the environmental costs of extraction, prompted a general consensus that water administration should be centralised, and managed to better accommodate environmental, economic and social needs. The Water Act 2007 (Cth) marked the federalisation of water resources; although it does not in itself replace the state administration of water, it creates the machinery for the implementation of a whole basin strategy for water. This includes mechanisms for limitations on extraction of water.

The Water Act 2007 (Cth) has as its guiding principle the idea of 'environmentally sustainable development' which is development that meets the needs of the present generation without compromising the ability of future generations to meet their own needs' [16]. However, the manner in which the needs of the environment and the demands of economic development are balanced remains a matter for debate.

The Basin Plan will, according to s.19 of the Water Act 2007 (Cth), 'provide for limits on the quantity of water that may be taken from the Basin water resources as a whole, and from the water resources of each water resource plan area'. These limits are expressed, in s.22(1) of the Act, as 'long-term average sustainable diversion limits' and 'must reflect an 'environmentally sustainable level of take', defined in s.4 of the Act to mean:

The level at which water can be taken from that water resource which, if exceeded, would compromise:

(a) key environmental assets of the water resource; or

(b) key ecosystem functions of the water resource; or

(c) the productive base of the water resource; or

(d) key environmental outcomes for the water resource

Section 4 of the Act defines 'environmental outcomes' to include ecosystem functions, biodiversity, water quality and water resource health.

Once the Basin Plan is set, state water resource plans must be consistent with the Plan. State plans must be submitted to the Commonwealth for accreditation in accordance with s 63 of the Act. Management of water resources within the auspices of the Plan still remain within the competence of the States.

\section{Basin clawbacks}

It seems inevitable that the Basin plan will result in reductions in agricultural water entitlements, although the amount by which they will be reduced is still at issue. The primary mechanisms by which water will be clawed back are water buybacks, modernisation of infrastructure offset by reductions in water entitlements, on-farm efficiencies and 'retirement' of irrigation systems. Other 
mechanisms have been foreshadowed, such as the metering of farm dams that collect overland flows [17].

Some of these alternatives involve payment of just compensation, measured by the market price of water or by calling for tenders. The Federal Government committed $\$ 3.1$ billion to buying back water entitlements to provide water for environmental flows and wetlands [18]. In the first tender, which closed in May 2008 , the government purchased only $\$ 50$ million of water entitlements, which amounted to 35 gigalitres, at an average price of $\$ 2124 /$ megalitre for high security entitlements and $\$ 1131 / \mathrm{mL}$ for low security entitlements [19]. Whereas buybacks may elicit concerns about the government 'pricing farmers out of the market' for water, more long term concerns arise where alternative mechanisms are used. In some jurisdictions, long established extractions have been reduced or abolished without any, or sufficient compensation, prompting arguments for the right to compensation.

The Constitutional protection against appropriation of property without just compensation only applies to the Commonwealth. Australian States do not, in general, have a constitutional obligation to pay compensation when they acquire a property right of an individual. Whereas State legislation provides the criteria for compensation for acquisition of land or other property, this is not a Constitutional requirement, nor does it arise as a consequence of the federal structure [20]. In Durham Holdings $v$ State of New South Wales the majority noted that

'Undoubtedly, having regard to the federal system and the text and structure of 'The Constitution of each State of the Commonwealth' ... there are limits to the exercise of the legislative powers conferred upon the Parliament which are not spelled out in the constitutional text. However, the limitation for which the applicant contends is not, as a matter of logical or practical necessity, implicit in the federal structure within which State Parliaments legislate [21].

The legislative technique by which the centralisation of water management in the Basin has occurred has meant that Constitutional compensation has frequently not been the primary issue. This pattern has served interjurisdictional legislative programs well over the past few decades [22], however recent High Court cases have challenged the Commonwealth's legal position in relation to compensation in such programs [23, 24].

The Water Act 2007 (Cth) provides for compensation in the event of a Constitutional 'acquisition' of property, but because of the interjurisdictional legislative techniques employed, the federal Act is not intended to result in the acquisition of property. The State water acts provide for compensation for acquisition of land or direct acquisition of water entitlements, but not for an attenuation of water rights through other regulatory mechanisms.

A Constitutional right to compensation is a feature of many written constitutions. It is 'designed to bar Government from forcing some people alone to bear public burdens which, in all fairness and justice, should be borne by the public as a whole' [25]. It is accepted that governments have the right to expropriate property [26] and it has been asserted that this right does not need to be scaffolded by Constitutional provision: 'The right of eminent domain, that is, 
the right to take private property for public uses, appertains to every independent government. It requires no constitutional recognition; it is an attribute of sovereignty' [27]. However, the Constitutional guarantee requires that expropriation be accompanied by compensation. In the Australian Constitution the power to acquire property arises in s.51(xxxi): The Parliament shall, subject to this Constitution, have power to make laws for the peace, order, and good government of the Commonwealth with respect to: ... The acquisition of property on just terms from any State or person for any purpose in respect of which the Parliament has power to make laws.' The Fifth Amendment to the United States' Constitution says 'nor shall private property be taken for public use, without just compensation.' State government action to claw back water allocations will not necessarily involve just compensation. In ICM the Commonwealth conceded that 'structural adjustment payments made by the NSW Government would not amount to 'just terms' under the Constitution [24]. It is likely that many of the arrangements entered into by other state governments similarly fail to meet the Commonwealth test for 'just' compensation. However, since most Basin clawbacks will arise as a direct consequence of state, rather than Federal legislation, the capacity of an irrigator to frame an argument for constitutional compensation is limited. In the United States, by contrast, the United States' Constitutional provisions extend to the States through the fourteenth amendment and the incorporation doctrine [28].

The right to compensation for appropriation of property is based on a longstanding normative principle, and it could be strongly argued that this principle should not be defeated by legislative devices. In Newcrest Mining (WA) Ltd v Commonwealth [20] Justice Kirby argues that restraints on the arbitrary deprivation of property can be traced back Article 52 of the Magna Carta 1215, which promised restoration of property to those deprived or dispossessed without lawful judgement, and continue through to Article 17 of the Universal Declaration of Human Rights, which states that everyone has the right to own property, and that "no one shall be arbitrarily deprived of his [sic] property' [29]. If Constitutional compensation can be linked to normative principle, then legislative devices that attempt to limit the availability or amount of compensation must be closely considered.

In ICM Justice Heydon at [178] considered the policy basis for reduction in water entitlements. He noted that

Unless they have a duty to pay compensation, legislatures will tend to experience undue temptation to acquire the property of citizens, and will tend to give into it, because this will usually be cheaper than employing some alternative technique. The threat that legislatures will acquire property without just compensation will result in people electing not to generate property by saving, or developing their property to less than optimal levels, or seeking a greater rate of return to meet the risk of acquisition, or pursuing investment opportunities in jurisdictions which do provide compensation for compulsory acquisition. The threat of acquisition without compensation thus damages incentives to invest. It damages the prospect of a dynamically efficient economy in which incentives to invest improve long-term social welfare by creating an optimal level and 
allocation of investment resources. To fulfil public purposes by taking private property without compensation is functionally equivalent to fulfilling those purposes by levying specific taxes on the owners of that property, and only those owners - a less efficient technique than levying taxes much more broadly in order to fund the just compensation. And there is a peculiar injustice in removing what may be the whole of one citizen's assets without compensation instead of funding compensation for that citizen by taking a very small part of the assets of all taxpayers [24].

Moreover, the Constitutional right to compensation is not limited to the provision of monetary equivalence. Justice Kirby in Wurridjal notes that 'The promise of "just terms" arguably imports a notion wider than the provision of monetary compensation' [30].

Obviously, the capacity of constitutional provisions to provide recompense for expropriation of water depends on other constitutional factors; in particular, whether the water is considered to be 'property' and whether there has been a constitutional 'taking'. No Australian case has effectively tested all of the aspects of the constitutional provision in relation to water, so none has tested the more remote aspects of the provision - expropriation of water that adversely affects the prospects of an entire region or community compensable, and if so, what compensation would be considered 'just'?

\section{Loss of amenity and the right to water}

Other normative arguments also arise. Water is a necessity both for life and for livelihood, and this has been recognised in normative statements both at international and at national level. The Universal Declaration of Human Rights article 25 and other peak agreements state that access to food and water are basic rights [29, 31-33]. The United Nations Committee on Economic, Social and Cultural Rights states at para 2 in particular that 'the human right to water entitles everyone to sufficient, safe, acceptable, physically accessible and affordable water for personal and domestic uses' [32]. This right has not been quantified; indeed, quantification of such a right would generate enormous conceptual problems, with the initial difficulty being what constitutes 'personal and domestic uses', and to what degree governments would be expected to subsidise the 'physical accessibility' of water.

Australia does not guarantee a 'right' to water; although the Water Act 2007 (Cth) s.86A(1) does require that Basin Plans be prepared having regard to the agreement between the states and the commonwealth that critical human needs are to be prioritized. Critical human needs are the needs for a minimum amount of water that can only reasonably be provided from Basin water resources required to meet: (a) core human consumption requirements in urban and rural areas; and (b) those non-human consumption requirements that a failure to meet would cause prohibitively high social, economic or national security costs.'

Section 86A(1) (a) acknowledges that this necessitates that conveyance water will receive first priority in the Murray system. This means that enough water must be retained in the river to deliver water 'as far downstream as Wellington in 
South Australia' (s.87A(4)) - just before the Murray River empties into Lake Alexandrina. This seems to require that the Murray would continue to flow virtually to the sea even in times of extreme drought to ensure critical human needs, even though this would entail enormous losses through evaporation and seepage and may not replicate natural flows, which would be minimal or nonexistent in extreme drought. Privileging the Murray River as a water carrier for the fairly minor domestic water extractions, despite the vagaries of Australian rainfall, both necessitates wastage of enormous volumes of water, and avoids the question of construction of infrastructure to carry water to regional settlements. The requirement that flow be maintained in natural carriers to supply 'critical human needs' in times of extreme water scarcity elevates short-term arrangements to supply water over the necessity to create infrastructure to meet town requirements. More problematically, however, it also points to a disparity between users. Losses through conveyance of town water through natural carriers are borne by others in the system who must have their allocations reduced to cover those losses.

Aside from the prioritisation of critical human needs, there is no particular guarantee that water will continue to be available to rural residents outside small towns. The Basin Plan and subsequent state plans deal with allocation issues. Issues of infrastructure are dealt with on a State level. Many actual and potential strategies being employed to claw back water allocations to irrigators threaten the capacity of individuals to access water. This is because water offsets are occurring through the privatisation, retirement, modernisation or reconfiguration of irrigation infrastructure - the infrastructure by which many rural people obtain water. Some of these processes will mean that individuals will now bear the entire cost of portions of the infrastructure. Some will mean that the infrastructure will be improved, thus becoming more expensive to maintain. This is problematic, since the system is now managed, or is projected to be managed, on a user-pays basis.

In an application of principles mandated by the Council of Australian Governments (CoAG) endorsement of the Productivity Commission Reforms and the National Water Initiative [34], the water sector in Australia is to be structurally reformed to be managed according to market mechanisms. This is intended to facilitate adaptation to water scarcity - an irony in the context of the floods covering much of the Basin in 2010. Structural reform of water delivery has been achieved mechanisms such as commercialisation, the application of the user pays principle, full cost recovery and structural change by unbundling the water product itself. All of these strategies have effects on the capacity of the system to deliver water to a rural population which is diminishing as a percentage of the greater Australian population. The Murray Darling Basin has a population density of 1.9 persons per square kilometre, compared with the national rate of 2.6, [35] and the rate of growth between 1996 and 2006 was only $5 \%$, markedly less than that of the rest of Australia at $12 \%$. The maintenance of infrastructure on a user-pays basis falls upon an increasingly small percentage of the population. As water clawbacks occur, the cost of the infrastructure as a proportion of the amount of water delivered increases. The sale of large water 
entitlements may also result in the reduced viability of parts of the infrastructure, leading to the problem of 'stranded assets'. Whereas water infrastructure has been supplemented in urban areas to reduce the impact of water shortage, in some rural areas water infrastructure has been reduced in area, or 'privatised', placing the risk of failure of the infrastructure on the individual.

\section{Conclusion}

How does this correspond with the necessity to prioritise 'critical human needs' or the development of an inchoate 'human right' to water? The parameters of a 'right to water' are unclear. There is no accepted indication as to the uses that may be included in any such right, the volumetric limits on use, whether it is acceptable to charge for water availability and/or usage, and whether such a right requires infrastructure to extend to all people, regardless of population density. In a user-pays system, reduced population numbers results in reduced viability for a whole range of services, from traditional government services such as education and health care to essentially private services such as petrol stations and banking services. The availability of water has been treated no differently if service provision is too costly to be maintained, there will be a trend towards contraction. As many parts of Australia are not served by natural water carriers, springs or viable underground water sources, this will mean that water availability will be dependent on massive investment in private infrastructure, and where private resources are insufficient, will fail altogether. This will result in further retraction of infrastructure. The promise to 'prioritise' critical human needs for the parts of the Basin that are served by infrastructure does not answer the issue for those in the Basin that are not served by the infrastructure, and as the Basin Plans are put into place this will become an increasing number.

The real issue, and it is one that all Western nations which have adopted economic rationalist positions must consider, is the long term sustainability of a policy to adopt strictly user-pays positions and retract infrastructure when this will restrict their long-term capacity to service a right to water to remote citizens. Clawing back water allocations with insufficient compensation from those who have purchased and utilised water 'rights' in good faith and for consideration in a semi-privatised system is not the best way to ensure that these citizens will otherwise be able to develop their own alternative water infrastructure. Clawing back allocations on the basis that infrastructure will be part of the compensation is certainly a more effective strategy, but more consideration has to be given to the consequences for all communities and their right to water when the strategy includes retraction of infrastructure.

\section{References}

[1] Holder, The Hon F W, Official Report of the National Australasian Convention Debates 1897, p 74

[2] McKernan, M, 'Coming to terms with the reality of a land burnt dry' The Australian November 132010 [Online] Available: www.theaustralian 
.com.au /national-affairs/coming-to-terms-with-the-reality-of-a-land-burntdry/story-fn59niix-1225952595679 [accessed November 14, 2010]

[3] Murray Darling Basin Authority (MDBA) Guide to the proposed basin plan, 2010 [Online] Available: thebasinplan.mdba.gov.au/guide/

[4] Rodgers, E., 'Inquiry called as basin plan anger grows' $A B C$ [online] Oct 14, 2010; http://www.abc.net.au/news/stories/2010/10/14/3038506.htm

[5] Lloyd, G, 'Great dividing rage over water' The Australian October 232010 [Online] Available: www.theaustralian.com.au/news/opinion/greatdividing-rage-over-water/story-e6frg6zo-1225942074914 [accessed November 17 2010]

[6] Murray Darling Basin Authority (MDBA), 'MDBA to commission further study of local community impacts' Media Release 17 October 2010

[7] Millar, R, 'Payback time as state dumps water plan critic' The Age September 262008 [Online] Available www.theage.com.au/nationa /payback-time-as-state-dumps-water-plan-critic-20080925-4o4e.html [accessed February 8 2010]

[8] Ryan, S., 'La Nina "here for decades"' The Australian January 14, 2011 [http://www.theaustralian.com.au/news/nation/la-nina-here-for-decades/ story-e6frg6nf-1225987421955 on $14^{\text {th }}$ January 2011

[9] http://www.theaustralian.com.au/in-depth/queensland-floods

[10] Cleary, P., 'How dams became a dirty word' The Australian January 15, $2011 \mathrm{http} / /$ www.theaustralian.com.au/news/opinion/how-dams-became-adirty-word/story-e6frg6zo-1225987429926 accessed 15 January 2011

[11] Maher, S., Owens, J., 'Tony Abbott's dam solution for flooded rivers' The Australian January 07, 2011 http://www.theaustralian.com.au/nationalaffairs/tony-abbotts-dam-solution-for-flooded-rivers/story-fn59niix1225983272814 accessed 14th January 2011

[12] Packham, B., 'Floods undermine Murray-Darling push to return water to environment, say irrigators' The Australian January 17, 2011 available at [http://www.theaustralian.com.au/national-affairs/climate/floodsundermine-murray-darling-push-to-return-water-to-environment-sayirrigators/story-e6frg6xf-1225989519110] accessed 17 January 2011]

[13] Wilson, L., 'Gillard to push ahead with Murray-Darling Basin plan despite floods' The Australian January 06, 2011 http://www.theaustralian.com.au/national-affairs/gillard-to-push-ahead-with -murray-darling-basin-plan-despite-floods/story-fn59niix-1225983012023 accessed 17 January 2011

[14] Gordon, The Hon J H Official Report of the National Australasian Convention Debates (1891), p 690

[15] Council of Australian Governments (CoAG) 'Intergovernmental Agreement on a National Water Initiative' http://www.coag.gov.au /meetings/250604/index.htm\#water_initiative 1995

[16] World Commission on Environment and Development (the 'Brundland Report') 1987, p 43 note 3 
[17] 'Farmers angry at meters on dams proposal' $A B C$ [online] $18^{\text {th }}$ January 2011 http://www.abc.net.au/news/stories/2011/01/18/3115232.htm?section=justi $\mathrm{n}$ accessed $18^{\text {th }}$ January 2011

[18] Wong, Sen. The Hon P, 'Next water buyback tender to open 15 September' Media Release 8 September 2008, [online] http://www.environment.gov.au /minister/wong/2008/mr20080908.html [accessed 18 March 2009]

[19] 'Water tender closes' farmonline Stock Journal 24 $4^{\text {th }}$ December 2008 [online] http://sj.farmonline.com.au/news/state/agribusiness-and-general /general/water-tender-closes/1392533.aspx on [accessed 18th March 2009]

[20] Newcrest Mining (WA) Limited v The Commonwealth of Australia (1997) 190 CLR 513, 650 (Kirby J)

[21] (2001) 205 CLR 399, 410 (Gaudron, McHugh, Gummow and Hayne JJ)

[22] For instance, the Corporations Act 2001 (Cth). Other examples are the Australian Consumer Law, which commenced January 12011.

[23] Arnold v Minister Administering the Water Management Act 2000 [2010] HCA 3;

[24] ICM Agriculture Pty Ltd v The Commonwealth [2009] HCA 51 (9 December 2009)

[25] Armstrong v. United States, 364 U.S. 40, 49, 4 L. Ed. 2d. 1554, 1561 (1960)

[26] Piedmont Triad Regional Water Authority v Unger, 154 N.C. App. 589, 572 S.E.2d 832 (2002), disc. rev. denied, 357 N.C. 165, 580 S.E.2d 695 (2003); Bank of NSW v The Commonwealth ('the Banking Case') (1948) 76 CLR 1 (Dixon J, 349-50) quoted in ICM (Hayne, Kiefel and Bell JJ, 134)

[27] Boom Co v Patterson, 98 U.S. 403, 406 (1879)

[28] Chicago B \& Q R Co. v Chicago, 166 U.S. 226, 41 L. Ed. 979 (1897)

[29] Universal Declaration of Human Rights 1948 http://www.un.org/en /documents/udhr/index.shtml

[30] Wurridjal v The Commonwealth of Australia [2009] HCA 2 [207] (Kirby J)

[31] World Health Organization 2003

[32] International Covenant on Economic, Social and Cultural Rights 1966

[33] United Nations Committee on Economic, Social and Cultural Rights 2002

[34] Intergovernmental Agreement on a National Water Initiative between the Commonwealth of Australia and the Governments of New South Wales, Victoria, Queensland, South Australia, the Australian Capital Territory and the Northern Territory, avail as pdf and rtf at COAG website http://www.coag.gov.au/meetings/250604/index.htm\#water_initiative>at15 September 2007

[35] Australian Bureau of Statistics, Water and the Murray Darling Basin - A Statistical Profile 2000-01 to 2005-06, Commonwealth of Australia, 2008, 24 